Abstracta Iranica Abstracta Iranica

Revue bibliographique pour le domaine irano-aryen

Volume 42-43 | 2021

Comptes rendus des publications de 2019-2020

\title{
Hannah-Lena Hagemann, Stefan Heidemann (eds.). Transregional and Regional Elites - Connecting the Early Islamic Empire: The Early Islamic Empire at Work
}

Christelle Jullien

\section{(2) OpenEdition \\ Journals}

Édition électronique

URL : https://journals.openedition.org/abstractairanica/53614

DOI : 10.4000/abstractairanica.53614

ISSN : 1961-960X

Éditeur :

CNRS (UMR 7528 Mondes iraniens et indiens), Éditions de l'IFRI

Référence électronique

Christelle Jullien, « Hannah-Lena Hagemann, Stefan Heidemann (eds.). Transregional and Regional Elites - Connecting the Early Islamic Empire: The Early Islamic Empire at Work », Abstracta Iranica [En ligne], Volume 42-43 | 2021, document 2, mis en ligne le 30 décembre 2021, consulté le 24 décembre 2022. URL : http://journals.openedition.org/abstractairanica/53614 ; DOI : https://doi.org/10.4000/ abstractairanica. 53614

Ce document a été généré automatiquement le 24 décembre 2022.

Tous droits réservés 


\title{
Hannah-Lena Hagemann, Stefan Heidemann (eds.). Transregional and Regional Elites - Connecting the Early Islamic Empire: The Early Islamic Empire at Work
}

\author{
Christelle Jullien
}

\section{RÉFÉRENCE}

Hannah-Lena Hagemann, Stefan Heidemann (eds.). Transregional and Regional Elites Connecting the Early Islamic Empire: The Early Islamic Empire at Work, I. Berlin : de Gruyter, 2020, 458 p., (Studies in the History and Culture of the Middle East 36), ISBN : 9783110666489. Open access (https ://doi.org/10.1515/9783110669800).

1 Cet ouvrage est consacré aux élites dans le nouvel empire instauré après la conquête arabe, appréhendées d'un point de vue régional à travers les frontières sociales, religieuses, géographiques et professionnelles.

2 - Stefan Heidemann, "Introduction: Transregional and Regional Elites - Connecting the Early Islamic Empire”

3 - Hannah-Lena Hagemann, Katharina Mewes \& Peter Verkinderen, "Studying Elites in Early Islamic History: Concepts and Terminology"

4 - Georg Leube, "Insult the Caliph, Marry al-Hasan, and Redeem Your Kingdom: Freiheitsgrade

5 of Kindi Elites During the $7^{\text {th }}$ to $9^{\text {th }}$ Century"

6 - Noëmie Lucas, "Landowners in Lower Iraq during the 8th Century: Types and Interplays" (cf. le compte rendu dans ce même numéro d'AbstIr) 
7 - Hugh Kennedy, "The Rise and Fall of the Early 'Abbāsid Political and Military Elite"

8 - Jürgen Paul, "Who Were the Mulūk Fārs?"

9 - Ahmad Khan, "An Empire of Elites: Mobility in the Early Islamic Empire"

10 - Amikam Elad, "Preliminary Notes on the Term and Institution of al-Shākiriyya in Early Islam (ca. 14-218 H/635-36-833 CE) Mainly According to the Arabic Sources"

11 - Alison Vacca, "Khurāsānī and Transoxanian Ostikans of Early 'Abbāsid Armenia"

12 - Simon Gundelfinger \& Peter Verkinderen, "The Governors of al-Shām and Fārs in the Early Islamic Empire - A Comparative Regional Perspective"

13 - Hannah-Lena Hagemann, "Muslim Elites in the Early Islamic Jazīra: The Qādīis of Ḥarrān, al-Raqqa, and al-Mawșil"

14 - Philip Wood, "Christian Elite Networks in the Jazīra, c.730 - 850" (cf. le compte rendu dans ce même numéro d'AbstIr)

15 - Petra Sijpesteijn, "Establishing Local Elite Authority in Egypt Through Arbitration and Mediation"

16 - Yaacov Lev, "The Civilian Ruling Elite of the Ṭūlūnid-Ikhshīdid Period"

17 - Cyrille Aillet, "Connecting the Ibādīi Network in North Africa with the Empire (2nd3rd/8th-9th Centuries)"

18 - Indices, Index of names, Index of places, Index of subjects.

\section{AUTEURS}

CHRISTELLE JULLIEN

CNRS, CeRMI, Paris 